\title{
How to Measure Overvaluation?
}

\author{
Boucheta Yahia \\ Maitre Assistant at the University of Sidi Bel Abbes \\ Lakhdar Adouka \\ Lecturer at the University of Mascara
}

\section{Doi:10.5901/mjss.2013.v4n2p239}

\begin{abstract}
This article aims to identify indicators and measurement criteria of an overvalued exchange rate. To achieve this goal, we will try to describe and analyze the main theories and measurement criteria overvalued exchange rate, to highlight the measurement criteria that explain the value or undervaluation of the exchange rate. Because it is essential for the understanding of international economic relations. We concluded from our study that there is never a single measure of undervaluation or overvaluation of a currency, but usually a "range" of estimates. The studied criteria presented in our paper are: The first criterion is that the equilibrium exchange rate of market over a long period. The second criterion is represented by the purchasing power parity (PPP). The third criterion is the normal rate of exchange, that is to say, that the rate should normally have an economy. The fourth criterion is the premium on the parallel exchange market
\end{abstract}

Keywords: PPP, price level, Lafay, Big Mac Index, GDP, Overvaluation, Exchange Rate,

\section{Introduction}

In recent years, the phenomenon of overvaluation monetary has changed. Recall here that in the global economic space, a currency is overvalued when the general price level of the country concerned is higher than comparable countries. The fact that differences in purchasing power parities are making purchasing power increasingly relevant. Studies relative economic size in nominal terms, converted from one currency to another by using the exchange rate does not establish fully the differences in price levels between countries. With a lower price level in developed countries, the demand for the same property can be satisfied with less. Therefore, GDP adjusted for the exchange rate is not an accurate indicator of the relative size of the two economies.

This is because the exchange rate market is not only based on the prices of goods and services exchanged.

International capital flows play a major role in establishing the level of a currency.

Therefore, a parity of purchasing power, which differs from the exchange rate market does not mean that a country's currency is overvalued or undervalued compared to another.

The exchange rates can be volatile, and their use to convert a product into a common currency may lead to unrealistic variations of such income or product.

For these reasons, the power parities are more appropriate for economic comparisons between countries. Converting expenditure data to a common currency and a common set of prices.

According to the theory, the exchange rate between two currencies is determined by the ratio of the general price level in both countries.

Thus, according to the purchasing power parity of a decline in domestic purchasing power of a currency, involving an increase in the general price level would be associated with a proportional depreciation of the currency on the foreign exchange markets.

Otherwise would lead to an appreciation of the latter.

Beyond the extent of the economic weight of countries, purchasing power parities are used to measure the economic well-being, or standard of living, using GDP per capita at PPP. The difference between the per capita GDP calculated at market exchange rates in these countries are relatively not as rich as they seem if you simply calculations at market exchange rates. 
Comparing the standard of living in the economies of these countries is difficult, and rank countries in order loses its meaning.

In many developing countries, low per capita income, the currency is overvalued, and the PPP rates, underestimating the GDP of these countries. The price level is actually very low, which is due to the large share of the economy of the product that are not traded internationally. The comparative price levels indicate whether the general price level for goods and services consumption for the average consumer in a country is higher or lower than that for an average household in another country.

PPPs are also used to make comparisons across time that is to say, the comparative study of economic variables in a given region over a period of time. This poses more difficulties than the spatial extent because the pricing structure changes over time. Thus, comparisons over time can be biased by various factors, such as changes in relative prices and relative volumes between countries.

Several empirical studies have tried to give a satisfactory answer to the validity of the PPP, and showed that in general it is not true in the short term.

However, in the long term validity of this relationship is much more controversial by a lack of consensus among economies. Therefore, other econometric methods have been developed so as to lead to clearer results.

This paper is to identify the criteria for measuring the overvaluation of the exchange rate. To achieve this goal, we will try to describe and analyze the main theories and measurement criteria overvalued exchange rate, to highlight the measurement criteria that explain the value or undervaluation of the exchange rate. Thus our paper is divided into three areas: PPP criteria, premium currency on the parallel market exchange rate normal, and the second axis is the use of some criteria to measure overvaluation in the case of the Algerian dinar, and Finally, the consequences of this overvaluation of the Algerian economy. models of exchange rate based on monetary and financial variables and finally, exchange rate models based on real and financial variables.

Most of the economic difficulties of the European Union are due to a misunderstanding of the crucial role of the exchange rate. Indeed, in recent years, the phenomenon of overvaluation monetary changed.

Recall here that in the global economic space, a currency is overvalued when the general price level of the country concerned is higher than comparable countries. For example, we can take the case of an American who buys the United States a basket of goods with a total value of $\$ 100$. If he comes to France and wants to buy the same basket, it cost him approximately 650 francs $\urcorner$ rate of "purchasing power parity" is currently CHF 6.50 for 1 dollar.

However, if it converts his dollars into French francs at the exchange rate of 5.20 francs to 1 dollar, he gets in return as 520 francs. This means that the general price level French then higher than U.S. prices, in a proportion of 650 to 520 , or $125 \%$. In this course, the French franc is overvalued by $25 \%$ against the dollar.

Such a result is observed in the real world, far from the perfect competition. In this case, in the global space, the relative price level of a country due to the combination of two variables: first, the rate of inflation compared to partner countries on the other hand, the nominal exchange rate. How can I get an overvalued currency? By skidding or inflation is not offset by a decline in exchange rate or by an increase in the exchange rate proves stronger than the differences observed in the evolution of domestic prices.

Classical Overvaluation resulting of the first mechanism, under a regime of fixed exchange rates. It happened several times in the international monetary system that had been established at Bretton Woods after the Second World War. France experimente-it at the end of the Fourth Republic, then the events of May 1968. After the collapse of the international monetary system, the same movements have arisen within the European Monetary System. In the case of France, in the early eighties, and inflationary pressures have played such an overstatement.

In the context of an economy in which the behavior of agents and the distribution of income were not changed, the classic overvaluation resulted fatally external deficit. It was therefore, sooner or later be corrected by a devaluation. While necessary, it was not considered a less shameful decision, sanctioning lax policy so far.

Overvaluation perverse meanwhile, results of the second mechanism, applicable to floating exchange rate regime that now prevails internationally. It is that national monetary policy is overly restrictive, while inflationary pressures have been contained and that markets have no reason to anticipate a future depreciation of the currency. Authorities cause an increase in the exchange rate for too long now interest rates too high. This behavior can be explained in several ways: obsessive phobia of inflation, the need to attract foreign capital to finance an external deficit, or the desire to maintain all costs, the parity with a partner who meets motivations above.

Unlike the case of the overvaluation classical, economy suffering from overvaluation perverse not subject to external constraint: when domestic growth is lower than the rest of the world, imports tend to increase less rapidly than exports, compensates for the lack of competitiveness of domestic production. As governments appear inflexible 
determination, and as long as the deterioration of the social situation does not lead to a political crisis, international markets are not likely to cause a currency crisis: they have no reason to doubt maintenance of an overvalued exchange rate against most foreign currencies.

To enumerate some measures of overvaluation or undervaluation of a currency presented The first criterion is that the exchange rate market equilibrium over a long period. The second criterion is represented by the purchasing power parity (PPP). The third criterion is the normal rate of exchange, that is to say, that the rate should normally have an economy. The fourth criterion is the premium currency on the parallel market

Consider now a country - in this case, the United States - whose currency is the main to have international reserve.

The rapid decline of the dollar, resulting in the fact that the euro over $\$ 1.30$ since November 2004, resulting in contradictory comments. Compared to what can we judge the overvaluation or undervaluation of a currency? Should reason through an exchange rate equilibrium exchange market, compared to the purchasing power parity, or compared to a normal rate of exchange?

\section{Measures of overvaluation}

\subsection{Taux equilibrium exchange market over a long period}

The first criterion is that the equilibrium exchange rate of market over a long period. United States, foreign trade of goods undergoes a profound deficit, which tends to accentuate and which far exceeds the amount that can obtain services. Current transfers deficit are both household private transfers that transfers public administration. As capital income, they were once surplus due to investment that U.S. multinationals had done outside, in recent years, this position has become increasingly negative.

The international role of the dollar is only part of the U.S. current account deficit is financed automatically by the accumulation of this currency by central banks outside. The other party must be filled by private capital inflows. However, the U.S. current account deficit widens by a cumulative process: it must be financed by capital inflows, which in the next period, in turn exacerbate the deficit in capital income and, therefore, the current account deficit. Capital inflows to the United States more and more difficult to follow this movement. This is why the overall balance of the balance of payments is negative, especially if Asian central banks are shifting to the euro.

Various calculations have been made to measure the tendency of the foreign exchange market. They lead most often to predict the movement will continue. The dollar may fall further, which means that the euro would rise to 1.40 or $\$$ 1.50. Observers conclude that the dollar is still currently undervalued. The adjective "overvaluation" is incorrect, because it means that the rate of market equilibrium gives an exchange rate necessarily satisfactory. In fact, it would be more correct to say that, on the market, the dollar is currently still over priced vis-à-vis the euro.

\subsection{Power Parity (PPP)}

The second criterion is represented by the purchasing power parity (PPP). This forms a theoretical benchmark, indicating a position in which the general level of prices in different countries would be identical after converted into the same currency all domestic prices. This would be obtained if the whole world was a perfectly homogeneous space, in regime of perfect competition. The reality is obviously very different. The real exchange rate then indicates the relative price level of an economy, measured in Gross Domestic Product. It is obtained by dividing the nominal exchange rate by the PPP rate, then multiplying the result by 100 to express it as an index.

Thus, the PPP rate of the euro vis-à-vis the dollar can be estimated currently at around $\$ 1.10$ per euro. When the nominal rate of the euro over $\$ 1.30$, the real exchange rate of the euro vis-à-vis the United States, which indicates the relative level of prices in Europe vis-à-vis the U.S. prices then rises above $100 \times(1.30: 1.10)=118$. By taking this test, some wrongly conclude that the dollar is "undervalued." In fact, the term is inaccurate because the app does not correspond to a normal exchange rate. It would be more correct to say that the dollar is currently the Deputy Joint vis-àvis the euro.

\subsubsection{The PPP and Big Mac index}

The Big Mac Index (the Index Big Mag: BMI) is based on the theory of PPP. This theory states that in the long term, the exchange rate between two currencies should adjust to equalize the price of an identical basket of goods and services 
across countries. Cart is chosen by the Economist Big Mac McDonald's is produced in almost 120 countries. The Big Mac PPP is the exchange rate as well as the burgers have the same price in the United States and any other country. BMI can see if their currencies are 'good' level. Indeed, comparing the Big Mac PPP with current rates observed in the foreign exchange market indicates whether a currency is over or undervalued.

McDonald's say the euro, the dollar and the yen are "strong" or "weak", this means that their market prices are above or below their "true" value. "To determine the percentage of over-or undervaluation of a currency, it must be determined what is called the equilibrium exchange rate," explains Valérie Mignon, professor of economics at the University of Paris -X-Nanterre, CEPII scientific advisor and head of the Department of Econometrics and modeling in finance-insurance EconomiX laboratory (UMR-CNRS). This fundamental value is calculated by economists on monetary matters. If all these experts generally agree on the determinants of exchange rates, the econometric models used are plural: there is never a single measure of undervaluation or overvaluation of a currency, but generally " range "of estimates.

The easiest way is to start from the shopping basket, according to the method of "purchasing power parity". This is how many goods and services can be purchased for an amount of money in a country compared to another. The British magazine The Economist has popularized this approach with its famous "Big Mac Index" which lists the price of the sandwich McDonalds around the world. Thus, the Big Mac cost on average $€ 2.94$ in the euro area at the end of January 2007, against 3.22 dollars in the United States, a purchasing power parity of $\$ 1.10$ per euro. By quoting $\$ 1.36$ on the market, the euro is overvalued and $24 \%$ (compared to \$1.10) after the "Big Mac Index". In contrast, the Chinese yuan is undervalued, according to this index, $56 \%$ against the dollar.

Of course, estimates of equilibrium exchange rates based on more complex calculations. "Several approaches exist to define the equilibrium value of the exchange rate, says Valérie Mignon. Among the best known are the purchasing power parity, the FEER approach (Fundamental Equilibrium Exchange Rate / Rate of exchange balance basic) approach BEER (Behavioral Equilibrium Exchange Rate / Rate of behavioral equilibrium exchange). According to the latter approach, the most used, the equilibrium value of a currency is determined on the basis of economic fundamentals of the country. was frequently retained as economic determinants of the value of the exchange rate in the long term, the following variables: the net foreign asset position (balance of foreign investment in the country and the country's investment abroad), the relative productivity (economic efficiency measured, for example, the production of the country relative to its volume of working hours) or the terms of trade (ratio of export prices to import prices) ".

To evaluate the exchange rate of two currencies, we also compare, for example, differences in inflation (change in consumer prices) between countries, differences in interest rates (the "price of money" ) and the current account balance (the balance of inflows and outflows). Indeed, the value of the currency should vary according to economic theory, based on these criteria, including funding to rebalance respective economies: a current account deficit should, all things being equal, lower the value of currency. For currency areas like the euro is the economic unit that is taken into account, as well as the states of the United States "share" the dollar despite the economic differences between California and Michigan, eg.

The conclusions drawn from these evaluations are discussed, for example, when compared currencies belonging to economies structurally very different. For Michel Aglietta, professor at the University of Paris X-Nanterre, the undervaluation of the Chinese yuan, and denounced often emphasized, is in fact a "false problem" justified by mutation of the economy.

There are two versions of PPP: the absolute version and the version on less restrictive.

\section{Absolute PPP}

It is based on the law of one price, the first central hypothesis.

The law of one price assumes that relative price levels of a country to another are equal. That is to say, expressed in a common unit, the prices of two identical country $A$ and country $B$ are equal.

Comparing a general price level. This is expressed thus: $\mathrm{e}=\mathrm{P} / \mathrm{P}^{*}$, where $\mathrm{P}$ is the price of good $\mathrm{x}$ in country $\mathrm{A}$, and $P^{*}$ is the price of the same good $x$ in country $B$, and $e$ is the exchange rate from PPP.

\section{The relative PPP}

It provides a comparison based on price variations, or from the price indices. This allows for comparisons over time between economies excluding the effect of inflation or productivity on prices in a country. Indeed, these two factors are 
critical in the formation of prices, comparing prices on the basis of the assumption of one price, we can extract part of the price corresponding to the effect of inflation or a change in level productivity. This is not possible with the exchange rate market.

Comparing a general price index. Several options are available for the relative PPP. We retain the following: $e=$ L.P / $\mathbf{P}$ *. If you are in a situation of absolute PPP (PPP is a respected country to another), then $L=1$. However, as reality is rarely absolute, $L$ allows price changes because $L$ is not constant.

\section{PPP uses:}

\section{Comparison in space.}

PPPs are primarily used for comparison in space: it is to take into account differences in living standards in the comparative study of different economic variables in different parts of the world at any given time.

\section{- Measure the size of the economy (GDP)}

The comparison between different countries GDP is distorted by the exchange rate market. In particular, the economies of developing countries are underestimated by the market exchange rate. For example, with data from 1999, Russia contributed less than $1 \%$ in the production of OECD countries based on the exchange rate market. PPP, we came to $3.5 \%$.

Fig 1: economics size\% of gdp total ocde,1999, selection countries

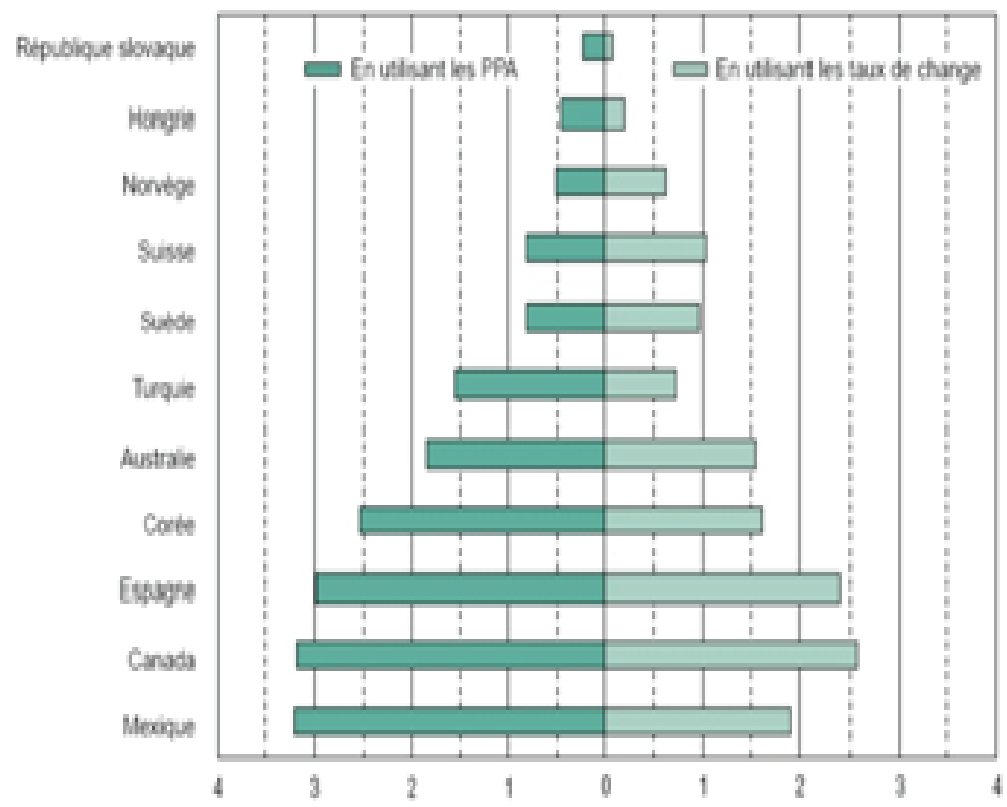

Source: OCDE, ppp results 19992002

The use of PPPs is therefore worth from developing economies in the global economy, as seen below. 
Fig 2.purchasing power parities transform the size of developing economies
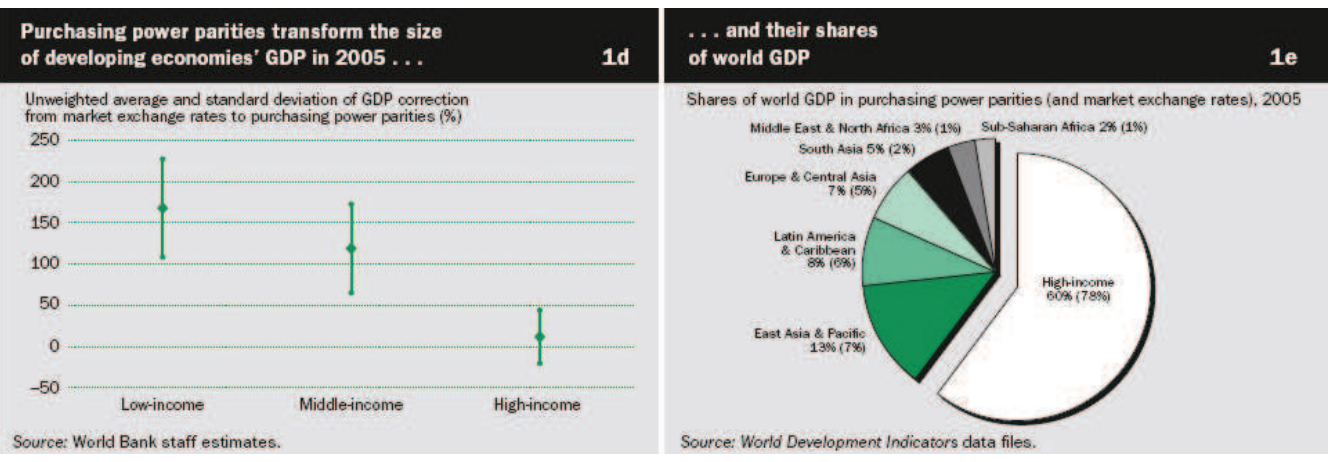

Source: World Bank

End of 2007, the program ICP (International Comparison Program) of the World Bank revised its method of calculating the PPP, which is the emerging economies, especially China and India have emerged $40 \%$ smaller than before $^{1}$. International rankings of this kind can take a very important for some states. Thus, at the time of publication of these statistics, Robert Zoellick, President of the World Bank, was quick to urge caution before drawing conclusions about poverty in China and India.

Fig 3. China and India's economies
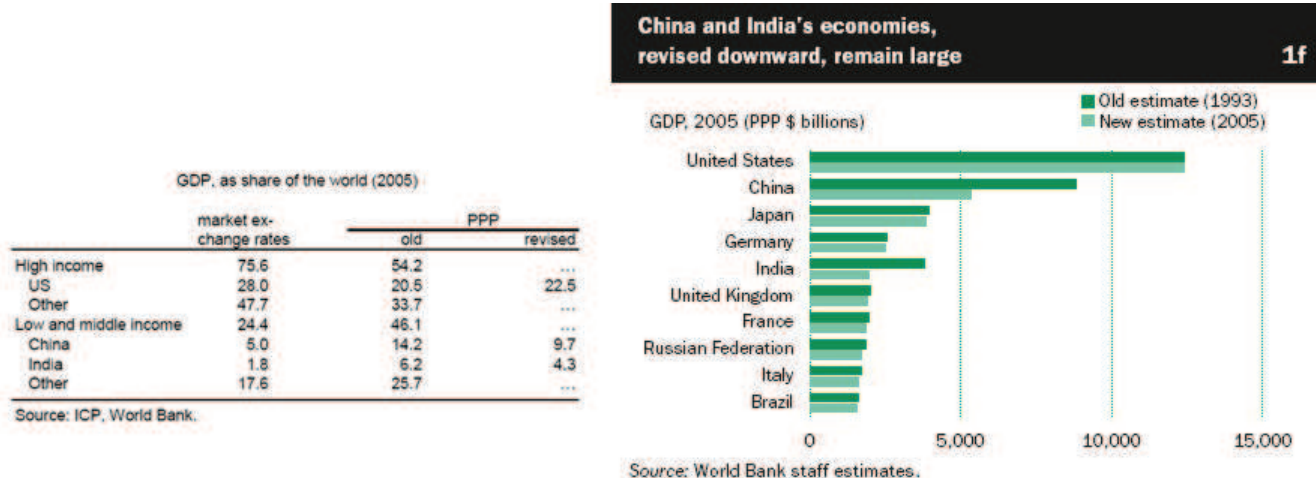

Source: World Bank

- Measure the level of life and economic well-being (GDP per capita)

Beyond the extent of the economic weight of countries, PPPs are used to measure the economic well-being, or living, using GDP per capita at PPP. The difference between the per capita GDP calculated at market exchange rates or using PPP is sometimes very large, like Japan or Switzerland in the table below. The inhabitants of these countries are relatively not as rich as they seem if you simply calculations at market exchange rates. This difference in outcome means that the currency is overvalued these countries (if the GDP / capita PPP is lower than the GDP / capita calculated by the exchange rate) or undervalued (if GDP / capita PPP> GDP / capita).

1 Scheherazade Daneshkhu, "China, India economies '40\% smaller'», Financial Times, 18 décembre 02007, http://www.ft.com/cms/s/0/36a2d566-ad82-11dc-9386-0000779fd2ac.html?nclick check=1. 
Fig 4. Two measurement of GDP/capita $1999,0 \mathrm{CDE} 30=100$
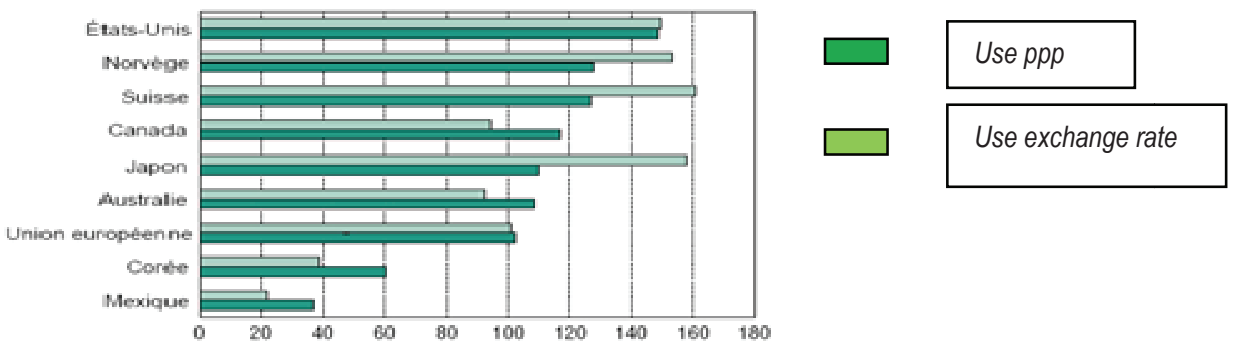

Source: OCDE, ppp results 19992002

Comparison of living standards in similar economies (such as major EU countries) is delicate, and rank countries in order loses its meaning. This is why the OECD and the World Bank prefer to determine regional groups or income. Regional groups of the World Bank are: "Low income, U.S. \$ 735 or less, lower middle income, from 736 to 2935 U.S. dollars; higher average income, 2936-9075 U.S. dollars, and high-income than 9,076 dollars EU. ' 2

\section{- Measure the price levels}

In many developing countries, low per capita income, the currency is overvalued, and there may be a considerable difference between the exchange rate and PPP rates, underestimating the GDP of these countries. The price level is actually very low, which is in large part in the economy of products not subject to international trade. For example, the price of a haircut in Delhi (Rs 20) is incommensurate with its Parisian prices (20 euros, more than 1000 rupees). The comparative price levels indicate whether the general price level for goods and services consumption for the average consumer in a country is higher or lower than that for an average household in another country.

There is a positive correlation between GDP / capita and comparative price level: the more a country is richer and the price level is generally high compared, and vice versa. This correlation is shown in the graph below.

Fig 5: GDP per capita and price level compared

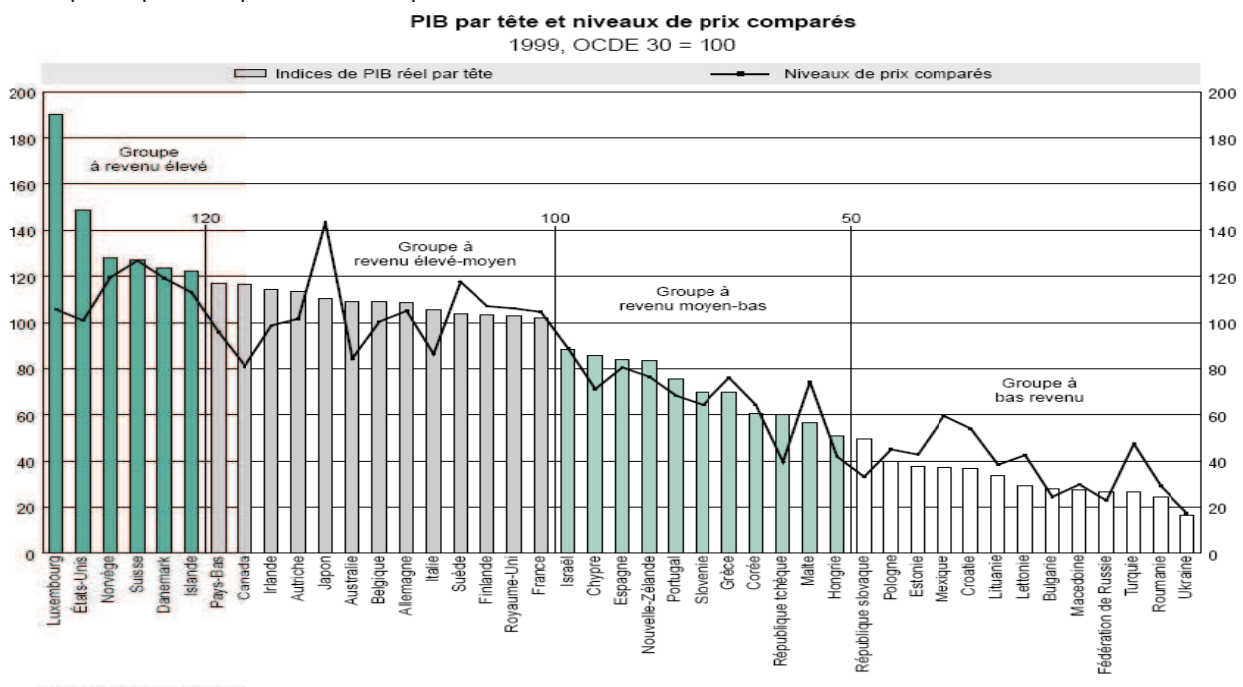

Source: OCDE, ppp results 19992002

${ }^{2}$ Banque mondiale, rank countries, $h$ ttp://www.banquemondiale.org/donnees/classification.htm. 


\section{- Measuring Productivity}

PPP is also used to compare the productivity of workers in different countries. Productivity is the ratio between the production and the means used to obtain it through the production volume in the calculation of productivity must be corrected using PPP. The study of the productivity app is particularly useful when linking with GDP / capita, because it helps to highlight the demographic structures and differences in the use of labor.

Fig 6: Estimation OECD of productivity levels of the workforce, 2007

\begin{tabular}{|c|c|c|c|c|}
\hline country & $\begin{array}{l}\text { Gross domestic } \\
\text { product at current } \\
\text { prices in millions of } \\
\text { national currency }\end{array}$ & \begin{tabular}{|l|} 
Purchasing power \\
parities for GDP \\
total national \\
currency per U.S. \\
dollar \\
\end{tabular} & $\begin{array}{l}\text { GDP per hour } \\
\text { worked at } \\
\text { current prices } \\
\text { in U.S. dollars }\end{array}$ & $\begin{array}{l}\text { GDP per hour } \\
\text { worked as } \% \text { of E-U } \\
\text { (USA = 100) }\end{array}$ \\
\hline Austria & 270837 & 0,9 & 45,5 & 86,8 \\
\hline Belgium & 334917 & 0,9 & 55 & 104,9 \\
\hline France & 1892241 & 0,9 & 52,7 & 100,6 \\
\hline Germany & 2422900 & 0,9 & 49,6 & 94,7 \\
\hline Greece & 228180 & 0,7 & 31,5 & 60 \\
\hline Ireland & 190603 & 1 & 56,8 & 108,4 \\
\hline Italy & 1535540 & 0,9 & 39,3 & 74,9 \\
\hline Japan & 516098400 & 120,1 & 37,3 & 71,2 \\
\hline Luxembourg & 36278 & 0,9 & 74,5 & 142,2 \\
\hline Mexico & 11139674 & 7,5 & 18,4 & 35,2 \\
\hline UK & 1401042 & 0,6 & 44,5 & 84,8 \\
\hline United States & 13741600 & 1 & 52,4 & 100 \\
\hline OECD TOTAL & & & 40,3 & 76,9 \\
\hline G7 countries & & & 47,1 & 89,9 \\
\hline Alena & & & 44,3 & 84,5 \\
\hline Oecd-Europe (except Turkey & & & 42,1 & 80,4 \\
\hline EU15 & & & 45,4 & 86,6 \\
\hline EU 19 & & & 41,8 & 79,8 \\
\hline Eurozone & & & 45,6 & 87 \\
\hline
\end{tabular}

Source: OCDE

\section{Comparisons over time.}

PPPs are also used to make comparisons over time, that is to say, the comparative study of economic variables in a given region over a period of time.

This poses more difficulties than the spatial extent because the pricing structure changes over time. Thus, comparisons over time can be biased by various factors, such as changes in relative prices and relative volumes between countries.

To combine spatial and temporal data, two methods are used: current PPPs and PPP constant. The reference for current PPPs are a series of PPP at a given time. Temporal data are then compared on the basis of currencies expressed in current prices, which allows the variation of prices and price structures over time. Comparisons between countries are made at current prices internationally.

PPPs constants describe the changes over time in constant prices and PPPs. Based on a reference year, data are extrapolated using inflation each respective country. The calculation is done by the PPP base year. The graph above shows GDP / capita of some OECD countries in constant PPP 2000 . 
Fig 7:The graph above shows GDP / capita of some OECD countries in constant PPP 2000

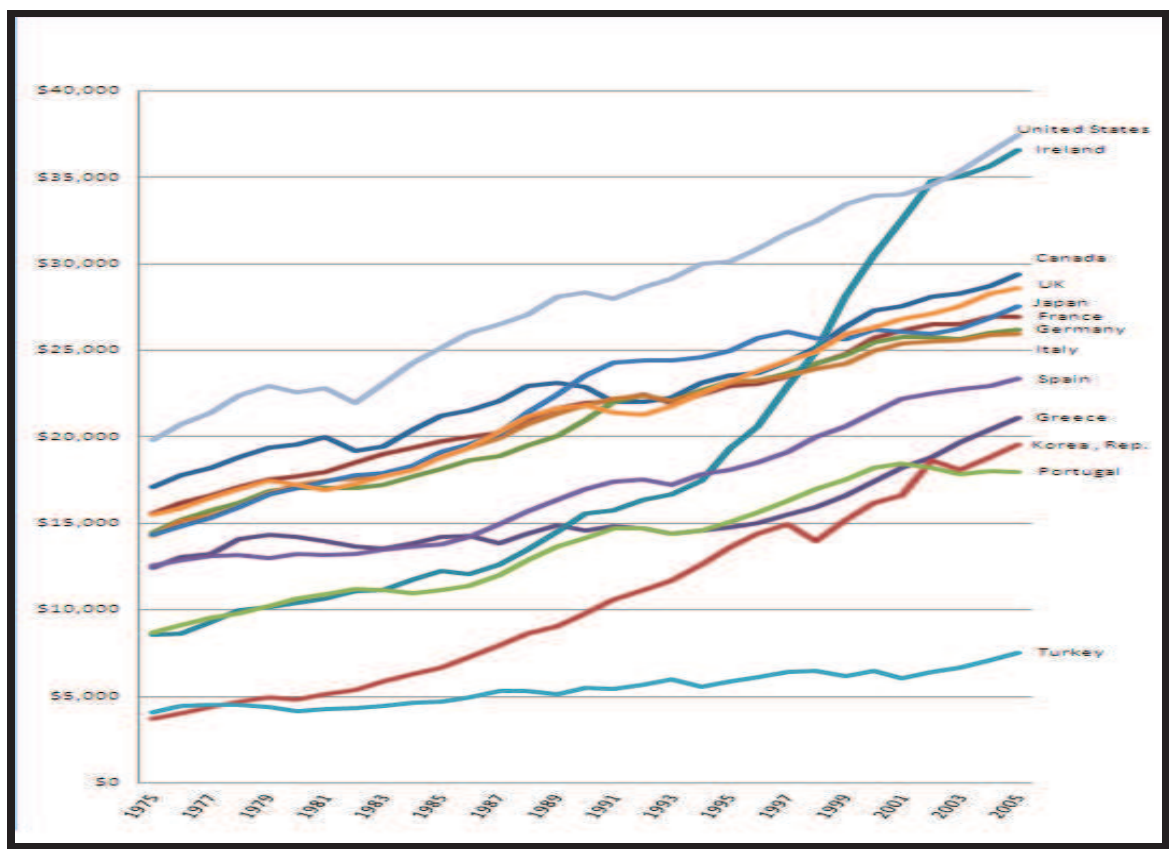

(Source: World Bank, WDI).

\section{Normal exchange rate}

The third criterion is the normal rate of exchange, that is to say, that the rate should normally have an economy. It is therefore necessary to examine the reasons why the United States has a current account deficit also abysmal. We know that the current balance of an economy is equal to the difference between the total savings of the nation and the real investment in its territory. On the one hand, the U.S. economy attracts more productive investment than the dollar is cheap.

The other, the fiscal balance of the United States, who had succeeded to the surplus at the end of the Clinton era, widened at breakneck speed.

This mechanism adds to the weakness of the old household savings rates, Americans have become accustomed to living beyond their means. The phenomenon has increased in the 1990s due to the wealth effect: believing increasingly wealthy as a result of the speculative stock market boom. Americans believed they could further reduce their rate savings. But the fall in share prices since 2000 has not had the effect of making up the savings rate: it was compensated for partly by further tax cuts, on the other hand, the development of mortgage loans to households to maintain a high level of consumption.

That the dollar is overvalued, it comes to be regarded as such a normal situation.

Given their behavior, both public and private, the U.S. savings pump the rest of the world since the early 1980s, leaving the resources of developing countries. By accepting the falling dollar, they also report their difficulties in other countries, particularly in Europe. But she had already suffered too expensive European currencies in the late 1980s and throughout most of the 1990s.

The exchange rate of a normal economy grows logically according to their level of development, due to three factors: the structure of the relative productivity of sectors, quality of specialization attractiveness of the area. If the private and public savings in the United States was normal, the U.S. economy, which is the most developed in the world, should thus have a real exchange rate higher than the euro, rather than up, should down to around $\$ 0.90$ per euro. That is why the dollar is becoming increasingly undervalued relative to its normal position vis-à-vis the euro. Passively accepting the 
fault of the U.S. economy, Europe is condemned to accept the rise of the euro in the coming years, thus undergoing the inexorable rise in unemployment.

\section{Premium on the parallel market exchange rate as a measure of overvaluation}

The fourth criterion is that the premium currency in the parallel exchange market to explain this last one refers to crosssectional studies on the link between democracy and performance overvaluation of the exchange rate (official) is approximated by the premium currency in the parallel exchange market under the assumption, not always explicit, that the parallel exchange rate is the equilibrium rate. However, if the appearance of a parallel exchange market is generally rooted in the overvalued official exchange rate, the premium on the market may reflect mainly the application of restrictions on the exchange and circulation of capital and property (Ghei and Kamin, 1999). Bahmani-Oskooee and Goswami (2006) who study the relationship between the level of democracy and the premium on the parallel exchange market favor an explanation in terms of capital flight: the lack of democracy explain capital flight abroad increasing the premium on the parallel exchange market. Tavares and Wacziarg (2001) argue that this premium is a broad indicator of the quality of governance and macroeconomic instability. The parallel exchange rate can therefore be extremely volatile, especially if the parallel market is narrow, and there are several multiple parallel markets, which limits its relevance approximation of an equilibrium rate. The use of the premium on the parallel market exchange rate as a measure of overvaluation raises problems at both conceptual and practical. In contrast, work to estimate the imbalances of the real exchange rate (the "misalignment") use measures more satisfactory because they are based on real theoretical foundations. The use of such a method, specially used in studies specific countries, which allows to take into account explicitly the link between democracy and exchange rate policy. This method, probably the most used studies in developing countries, is exposed in detail in Baffes et al. (1999).

Overvaluation of the exchange rate as an instrument of urban bias.

In the years 1970-1980, the exchange rate of the Malagasy franc was certainly overvalued. Indeed, the nominal exchange rate remains anchored to the French franc, while

Madagascar withdrew from the franc zone and facing a drop in foreign direct investment. Severe restrictions on imports and foreign exchange and production overcapacity in the industry are also a sign of overvaluation at that time (Pryor, 1990). Although it is an imperfect indicator of imbalances in the exchange rate as explained above, the premium currency on the parallel exchange market reveals a probable overestimation of the order of $50 \%$ to $100 \%$ from the mid1970s.

Figure 8. Premium currency on the parallel exchange market (parallel exchange rate on the official exchange rate)

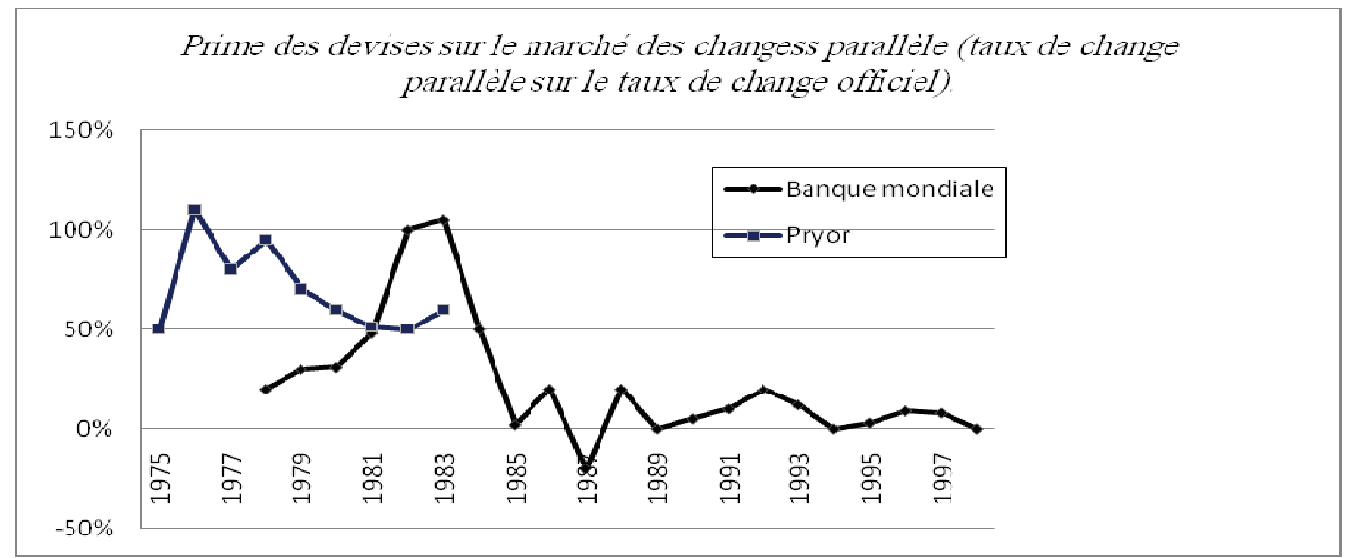

Source: World Bank. Development Index in the world and Pryor, 1988; black market in Antananarivo. Further information on the bonus: The Institute Free the world shows $0 \%$ in 1970, 25\% in 1975 and 50\% in 1980. Dean et al (1994) gives an average of $37 \%$ in $1980-87$ and $13 \%$ in $1988-92$ 
Overvaluation of the exchange rate appears to be relatively well measured contemporary dictatorship, it could be interpreted as an instrument of urban bias applied rationally by the dictatorial regime following the thesis of Bates (1981).

\section{3 .La detection overvalued Algerian Dinar}

\section{1 the detection criteria of the overvaluation of Algerian Dinar}

There are certain criteria that can detect the existence of which not overvalued nominal exchange rate against foreign currencies and foreign currencies. We include it for the balance of the balance of payments, the level of reserves, the real exchange rate, the index of the real effective exchange rate, index of nominal effective exchange rate and market premium parallel exchange. To detect the overvaluation, we consider the first two criteria, while applying the method Lafay.

Thus, with regard to:

(i) the criterion of balance of payments: when the balance of payments is characterized by a structural imbalance and the exchange rate is kept constant, the price of the national currency is overvalued;

(ii) the criterion of reserve level: in fixed exchange rate regime, if the level of reservesdecrease continuously, while the exchange rate of the national currency is maintained at a constant level administratively, the exchange rate of the currency is overvalued.

The combination of these two criteria, we can see that when the balance of payments of a country is in a state of permanent deficit, foreign exchange reserves are dwindling. If a fixed exchange rate regime, the exchange rate remains invariant and administered by the State with an inconvertible currency, bid on the foreign exchange market is structurally lower demand. In this situation the exchange rate tends toward a level of overvaluation.

(iii) the method Lafay: we refer to the conclusion of Roggff (1996) andLahrech-Revil (1998), as regards the study of the relationship between the level ofcompetitiveness and standard of living, to show that the Algerian dinar was overvalued. In effect these authors showed that changes in the level of competitiveness is bound correspondingly in life achieved by the country. In other words, the more developed the country, the more its real exchange rate tends to rise. A country whose standard of living is low and that the real exchange rate is close to that of industrialized countries have an overvalued currency. In contrast, a country whose standard of living is high and the real exchange rate relatively low, would be an undervalued currency

This method is used to demonstrate Lafay that Algeria to a standard of livingvery low, and that the exchange rate is overvalued comparisons exchange rateRated developed countries.

Lafay proposed a method of analysis, based on the comparison between the rate ofreal exchange rates and levels of development of the economy compared to a reference area. Lafay argues that in the short term and before the production structure is undergoing change, the variables' real exchange rate relative (CRRT) and GDP per capita relative (PIBTR) "are the determinants of current balance:

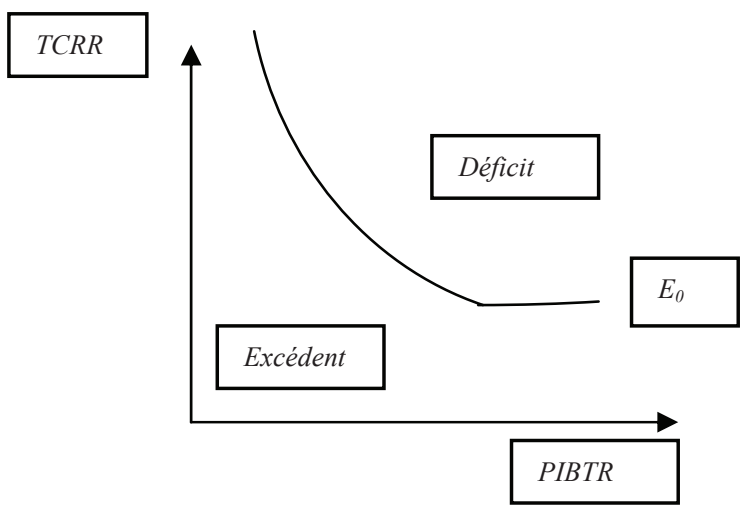

Fig 9. Equilibrium curve current Lafay 
According to the figure, the combinations (PIBTR, CRRT) above or below

EO reflect the respective situations of deficit or excess current. Different combinations located along the curve E0 realize balances currents without affecting the structure of the economy.

A long-term (changing structure of the economy) this curve moves, varying at the same time, different combinations of balance.

According Lafay curve E0 can take the following mathematical form:

$P T \times R_{\gamma^{n}}^{\lambda}=c$

with:

PT: relative GDP per capita converted by the rate of APP;

$\mathrm{R} r$ : real exchange rate relative;

$\lambda$ : real coefficient;

c: constant.

For Lafay, there are several cases expressing the ability to adjust the exchange rate, depending on the value of $\lambda$ :

(i) if $\lambda>1$, the real exchange rate will be very effective in restoring the balanceexternal.

(ii) if $\lambda<1$, the exchange rate loses its effectiveness for the restoration ofbalance by volume. We often encounter this case in countries that control their prices and foreign trade, such as Algeria in the period 60-89,.

(iii) if $\lambda$ tends to zero, is the case of an economy with sticky prices. According to the classification of Lafay, these countries are underdeveloped and exporters of primary materials.

To test the validity. This approach, we try to apply the model of Lafayin the case of the Algerian economy. Model variables (CRRT, PIBTR) should be calculated relative to a reference area. In our case, we take the Etas States.

Variables are calculated as follows:

With:

$$
P I B T R=\frac{P I B T}{P I B T^{*}} X 100
$$

PIBT: GDP per capita household calculated with the PPP rates

PIBT *: GDP per capita foreign calculated with the PPP rates

TCRR: Exchange rate relative

PIBTR: GDP relative Algerian economy with respect to the reference area (USA)

The GDPppp and GDPppp * are GDP, domestic and foreign rates computed with

PPP.

The estimated coefficient $\lambda$ for data Algerian, according to the following formula Lafay:

$\log$ PIBTR $=-\lambda \log$ TCRR $+\mathrm{C}$

After estimation by the method of least squares on data from 1975-2005, we

have obtained the following result:

$\log$ PIBTR $=-0.29 \log$ TCRR $+4,08$

We try, after that, to see the validity of the parameters estimated by the Student $t$ test.

Tab.2.41. Validity test parameter.

\begin{tabular}{|c|c|c|c|}
\hline coefficient & t-statistic & t-tabulated & significance \\
\hline$\lambda$ & $-24,25$ & 2 & significant \\
$c$ & 88,29 & 2 & significant \\
\hline
\end{tabular}

From Table 2.41 the estimated parameters are significant. The tests for autocorrelation of errors by the DurbinWatson ( $D W=0.97$ ), tells us that the errors are not correlated. Based on the value of $R 2$ (coefficient of determination), we can say that the exchange rate relative says strongly (95\%) variable relative GDP per capita. 


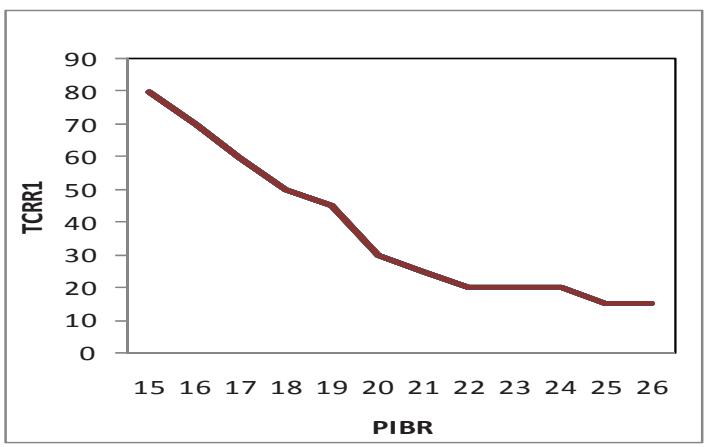

Fig.10: Equilibrium curve current Lafay.

On the estimated parameter $\lambda(\lambda=0.29)$, it is less than one and closer to zero. This estimate allows us to position the Algerian economy in the category of countries with underdeveloped fixed price and exporters of primary materials, including adjusting the external real exchange rate is not very effective.

Having demonstrated that Algeria is positioned in the category of countries under developed, so among the countries that have a low standard of living. We compare the TCN Algeria and that of France * (France we took as a reference country for developed countries).

Tab.2.42. Evolution of TCN in Algeria and France (taking the year 1970 as the base year)

Source: IMF

\begin{tabular}{|c|c|c|c|c|}
\hline & 1974 & 1978 & 1982 & 1990 \\
\hline Algeria & 84,7 & 84,7 & 84,7 & 181,4 \\
\hline France & 97,5 & 91,4 & 133,1 & 110,2 \\
\hline
\end{tabular}

From Table 2.42, we can say that the nominal exchange rate is closethe nominal exchange rate of France, during the period from 1974 to 1989. However, the standard of living between the two countries differed. This justifies, while referring to the result of Rogoff, the Algerian dinar was overvalued during this period.

\subsection{The extent of overvaluation}

There are several methods to determine whether an exchange rate deviates from itsequilibrium path. These methods were the supports for the work on the exchange rate equilibrium Williamson (1983) and Edwards (1989).

These studies have attempted to model the level of the real exchange rate based onreal economic factors and financial resources to find a real exchange rate, which ensures internal and external balance.

By calling the estimation of the rate of real exchange rate equilibrium real exchange(TCRE), misalignment indicator is calculated as follows:

\section{observed exchange rate - exchange rate equilibrium real}

real exchange rate equilibrium

For now, we focus on two simple methods of measuring the rate of overvaluation. The first is based on the standard PPA. Under this method the overvaluation of a currency can be determined from the evolution of its relative purchasing power. If the purchasing power of the dinar decreases relatively to the foreign currency, while the nominal price remains constant, the dinar is becoming increasingly overestimate.

To calculate the rate overvaluation, we need to calculate the power index purchase the dinar against the dollar. This is the inverse of the price index consumption of Algeria, expressed in dollars. We get it by multiplying the index by the consumer price index of nominal exchange rate. The following tables show the calculation procedure: 
Tab.2.43. Evolution of the price index (CPI), the index of the nominal exchange rate of the dinar against the dollar (NCIT), the index of relative purchasing power (IPAR) and the rate overvaluation ( TSUREV) taking the year 1970 as the base year.

\begin{tabular}{|c|c|c|c|c|c|}
\hline & 1974 & 1977 & 1982 & 1986 & 1990 \\
\hline IPC & 1,18 & 1,57 & 2,75 & 3,9 & 1,46 \\
\hline ITCN & 1,18 & 1,19 & 1,07 & 1,05 & 0,55 \\
\hline IPAR & 71,6 & 53,39 & 33,89 & 24,42 & 32,1 \\
\hline TSUREV & 39,58 & 87,29 & 195,8 & 309,5 & 211,5 \\
\hline
\end{tabular}

Source : FMl et ONS.

Table 2.43 is interpreted as follows, including the third and fourth line:

The purchasing power of the dinar against the dollar in 1974 is 71.6 that of 1970 . That is to say, in 1974, a dollar at the official exchange rate is only 71.6 Algeria buys what he bought in 1970.

In 1986, the same purchasing power is only a quarter of that of 1970 . We note that the TCN from 4.9 in 1970 to 4.7 in 1986: an appreciation of $5 \%$.

Overvaluation of the dinar dollar terms, expressed relative to 1970 is $39.6 \%$ in 1974 . She goes to $87.29 \%$ in 1977 , and $309.5 \%$ in 1986 and 211.5 in 1990.

The second method is to measure from the premium market exchange parallel. Before we start implementing this measure. It is necessary to clarify the causes of the emergence of the parallel market in Algeria on the one hand, and that is the feature

The causes of the existence of a parallel market can be summarized in the pointsfollowing:

i. During the period 1970-1989, Algeria had adopted exchange control. He had encouraged fraud. This has facilitated the development of the black market;

ii. Algeria, to regulate the exchange, had established quantitative restrictions;

iii. the Bank of Algeria refusing to fully meet all the demand for foreign exchange at the official rate, the plaintiffs have not satisfied returned to the unofficial market (market occult).

The feature of the parallel exchange market is the gap that may exist between theofficial and the parallel course. If this difference is positive currency is overvalued, if no currency is undervalued. If the difference is zero, we are in a case of alignment. For this reason the IMF and the World Bank consider the parallel exchange rate as the magnitude of the necessary adjustment devaluation of savings in situations of dual exchange market. Thus, we can say that the parallel exchange rate is the real exchange rate equilibrium. The exchange of this type of market are determined by the law of supply and demand for currencies.

Premium formula that allows us to measure the overvaluation is as follows:

Overvalued official exchange rate $=\quad \frac{B_{t}-E_{t}}{E_{t}}=\frac{B_{t}}{E_{t}}-\mathbf{1}$

And with Bt and represent the official exchange rate and the parallel exchange rate in year t. The calculation of this premium is recorded in Table 2.44 below:

Tab.2.44. Extent of overvaluation $\%$ of dinar from being parallel chnage Algerian dinar against the French franc.

\begin{tabular}{|l|c|c|c|c|c|}
\hline & 1974 & 1977 & 1984 & 1987 & 1989 \\
\hline$E_{t}$ & 1 & 1,3 & 0,61 & 0,8 & 1,38 \\
\hline$B_{t}$ & 1,4 & 1,5 & 4 & 4 & 6 \\
\hline $\begin{array}{l}B_{z} \\
E_{t} \\
\text { en } \%\end{array}$ & 40 & 15,3 & 555,7 & 400 & 334,7 \\
\hline
\end{tabular}

Source: Bank of Algeria in H.Bali "inflation and poor development in Algeria" (1993) and H.Henni. "Essay on the economy" (1991) 


\section{The consequences of an overvalued real exchange rate}

Consequences dune overvaluation of the real exchange rate are key in their explanations:

- Expansionary policies under domestic demand to an unsustainable level - the loss of export earnings (a drop in the prices of exported goods);

- Payments deficits;

- Faster inflation in the national economy in the country trading partners;

- A fiscal deficit important;

- The protection of the national economy;

- Debts;

- Low productivity and lack of competition at national level generates higher costs for partner countries.

The consequences of overvaluation are actually harmful to an economy. These can be summarized as follows:

- it makes imports artificially cheap, while outdoing the production of exportable goods.

$\square \quad$ it reduces the external competitiveness of the economy. Which leads to a decrease in domestic production, is the unemployment rate, and decrease the level of tax revenue.

The loss of external competitiveness resulting in increased imports and reduced exports. Even when the subsequent trade deficit is financed by reserves or by borrowing, it is generally not wise to exhaust its reserves or incur debts which sooner or later must be repaid by trade surpluses.

The decrease in production, increased unemployment and the loss in tax revenue are due to fact that the industries flowing their product on the market national realize less profit because of the increase in imports. They will then close slowly. Export industries in turn, will reduce production and gradually close, because their products are not competitive on the world market. The closure of industries then causes increased unemployment and declining tax revenues, as a result of the contraction of the tax base.

- The devaluation pressure is a measure that is usually necessary authorities, because of the crisis in the external balance and speculative attacks against the exchange rate from asset markets. Speculators indeed anticipate devaluation and turn to foreign currencies and other assets. They also cause an acceleration in imports, which are undervalued exports and suspensions pending the resumption of the competitiveness of their products.

- On the domestic financial markets, importers will borrow heavily to finance their imports. Which will drive up interest rates, deteriorating then the investment and other sectors of the economy.

\section{L impact of the overvaluation of the Algerian economy}

The control system of exchange with foreign exchange rationing implies that, as the exchange rate of the Algerian dinar (DA) overvalued contributed to swelling imports without protection to domestic production

The abundance of foreign exchange earnings of the 70 had stimulated the appreciation of the national currency, while negatively affecting the non-oil sectors of the national economy. Thus discouraging the export and handicapping the diversification sought in the field of production.

Tab.2.45. Variation of term of trade (in\%) and of the variation of effective exchange rate real (in\%).

\section{Source IMF (1988)}

\begin{tabular}{|l|c|c|c|}
\hline & 1980 & 1984 & 1986 \\
\hline Terms of trade & 47,3 & -13 & -53 \\
\hline REER & $-1,6$ & 7 & $-7,7$ \\
\hline
\end{tabular}

Moreover, since 1970, the exchange rate of the DA, vis-à-vis the dollar and Western currencies, had ceased to be rigid. The weighting system does not take into account current revenues realized with the outside. Which had led to an underestimation of the weight of some currencies in the basket currency to the detriment of other currencies.

According to economists Algerian dinar Algerian overvalued was the main cause of the current account deficit. In addition, it reduced the profits of industries producing tradable goods, while contributing to a shift of resources in favor of non-tradable sectors. Implying that additional demand for goods is met by imports. 
The appreciation of the currency effect to generate pressure from the goods-producing sector is exchangeable for a production implementation. However, if certain sectors are protected, others are not and therefore suffer more.

Accordingly, an overvalued exchange rate, relative to foreign currencies implies that the prices of imports from these countries are very low compared to domestic prices. What kind of accent to the preferences of domestic enterprises to foreign products, thus reducing the requirements of the continuing process of industrialization and therefore disadvantage the growth and development of the country.

This encourages enterprises has neglected their main activity is the production, dedicated to the business of marketing of imported products thus achieving an annuity on imports. In effect, these companies had made no desired objectives such as the protection of national production, the stability of DA and import substitution.

Also, overvalued exchange rate necessarily implies lower prices of imported products, but it can in no way affect the imported inflation. To achieve the objectives (protection of national production, ... stability of the national currency), the exchange rate policy is required to meet the following two criteria:

- Fully neutralize imported inflation;

- Keep only the value of the national currency against the average western currencies, compensating for specific dollar fluctuations.

Imported inflation rate implies an appreciation of the high exchange rate vis-à-vis the dollar, to offset the depreciation of the dollar vis-à-vis the SDR. But the increase of the exchange rate does not take into account the inflation differential with Western countries.

When there is divergence between the cost of a country's exports and those of competitors, it is the country where the exchange rate is overvalued losing business opportunities. Similarly, if import prices are relatively low, consumers prefer imported products to local products, highlighting the problem of unemployment.

Overvaluation is usually an incentive for foreign capital to invest in countries undergoing the appreciation of its currency. This was not the case in Algerian economy, due to the inconvertibility of the dinar.

We can identify the effect of overvaluation on some sectors of the economy, as follows:

(i) for the industrial sector overvaluation of the Algerian dinar (DA) made artificially cheap international purchases products from abroad and prevented, thus the substitution of domestic production for imports. Similarly, the overvaluation of the DA involved in the import of capital goods, to lower the technological processes towards capital intensive production to the detriment of the use of labor abundant and, therefore, the reduction of unemployment.

(ii) With regard to finished products manufactured overvaluation prevented domestic producers to be competitive and their investments were disadvantaged in the line of production.

(iii) The agricultural sectors were marginalized and did not have much of protection. This explains the increase in imports of food, consumer goods, food ...... etc, want to achieve social satisfaction. The producer price of agricultural commodities were long remained poorly paid and did not result in improved total production. So this. Overvaluation damaging their crops.

(iv) Regarding non-factor services (international transport, tourisms ....), the DA overvaluation discouraged exports and stimulate imports. This had caused the deficit in the trade balance.

(v) Regarding factor services (dividends, interest .....), the overvaluation stimulated the release of funds and braked entries. She averted repatriation a portion of the national currency savings of emigrants abroad channel Official banks to the parallel market.

\section{Conclusion}

We concluded from our study that there is never a single measure of undervaluation or overvaluation of a currency, but usually a "range" of estimates.

The studied criteria presented in our paper are:

The first criterion is that the equilibrium exchange rate of market over a long period. The second criterion is represented by the purchasing power parity (PPP). The third criterion is the normal rate of exchange, that is to say, that the rate should normally have an economy. The fourth criterion is the premium on the parallel exchange market.

There are certain criteria that can detect the existence of which not overvalued nominal exchange rate against foreign currencies and foreign currencies. We mentioned this to the balance of the balance of payments, the level of reserves and the premium market exchange parallel. 
The consequences of an overvalued real exchange rate are the main explanations in their expansionary policies under domestic demand to an unsustainable level, the loss of export earnings (a drop in the prices of exported products ...) and For our country, we can say that the overvalued exchange rate had an adverse effect on domestic production and exports. He had reduced the profitability of exports, thereby discouraging the promotion of non-oil exports. The undervaluation of currencies allow domestic firms to use easy loans on the international financial markets without large financial penalty, since they were performing in overvalued dinar, compounding the country's foreign debt. Compression of exports and imports related to swelling of the overvaluation of the DA were powerful factors limiting investment and braking diversification of production structures and growth.

Consequence of the decline in exports dinar and increase the import was the deterioration of the trade balance. Overvaluation of the DA was compressed local revenues from the hydrocarbon sector, which remains the source of substantial income and other taxes. This compression has reduced oil taxes, which automatically resulted in a deficit of treasure.

\section{Bibliography}

Adouka L. (2010), "Modeling the exchange rate of the dinar Algerian using ECM models", PhD thesis.

Bali H. (1993), "Inflation and the poor development in Algeria," Edt.OPU, Algiers.

Bates RH, 1981, Markets and states in tropical Africa, Berkeley: University of California Press, 1981.

CommSec, iPod Index, http://www.comsec.com.au/public/news.aspx?id=809.

Dean, J.M., S. Desai and J. Riedel, 1994, Trade policy reform in developing countries since 1985: A review of the evidence, World Bank Discussion Paper 267, Washington DC.

Daneshkhu, Scheherazade, "China, India economies '40\% smaller'," Financial Times, December 18, 2007, http://www.ft.com/cms/s/0/36a2d566-ad82-11dc-9386-0000779fd2ac. html? nclick_check = 1 .

Ghei N. and Kamin SB, 1999, The use of the parallel market rate as a guide to setting the official rate, in LE Hinkle and Montiel PJ (1999), Eds, Exchange Rate Misalignment: Concepts and Measurement for Developing Countries, p. 405-464. New York: The World Bank.

G. Lafay (1985), "Real exchange rate dynamics and international trade", in protectionism, Economica, Paris.

Henni A., "essay on the economy" Ed.Enag 1991.

IMF (1998), "Algeria: Stabilization and Transition to market economy", IMF occasional paper No. 165.

FL Pryor, 1990, Malawi and Madagascar, the Political Economy of Poverty, Equity and Growth, A World Bank Comparative Study, Oxford University Press, The World Bank.

J. Williamson (1983), "The Exchange rate system", Institute for InternationalEconomicsWashington, DC.

J. Tavares and R. Wacziarg, 2001, How democracy affects growth, European Economic Review 45, p.1341-1378.

K. Rogoff (1996), "The Purchasing Power Paity Puzzle", Journal of Economic Literature, vol.XXXIV, June

Levesque.J and Geraghty.K, "Conference on economy Fabrice Bittner power parity (PPP)"

Laharech R. (1998), "Real exchange rate and development" thesis.

OECD Statistics Brief - purchasing power parities: Measurement and Uses, March 2002, http://www.oecd.org /dataoecd/32/31/2078201.pdf.

OECD, OECD in Figures 2008, http://www.oecd.org/dataoecd/22/43/41742094.pdf.

Ong, Li Lian, The Big Mac Index, Applications of Purchasing Power Parity, New York, 2003.

S. Edwards (1989), "Real Exchange Rates, Devaluation and Adjustment, Exchange Rate Policy in Developing Countries, MIT Press, Massachusetts.

Stud. M (2008) Democracy and overvaluation of the exchange rate:the case of Madagascar, University of La Réunion.

World Bank, Focus on the new PPA and the Chinese economy, http://go.worldbank.org/K6DOHGBYU0.

World Bank, http://siteresources.worldbank.org/INTCHINA/Resources/318862-1121421293578/cqu_jan_08_en.pdf.

World Bank, World Development Indicators 2008, http://siteresources.worldbank.org/DATASTATISTICS/ Resources/WDI08 section1_intro.pdf 
